\title{
The Korean Society of Hypertension Guidelines for the Management of Hypertension in 2013: Its Essentials and Key Points
}

\author{
Hae-Young Lee ${ }^{a} \quad$ Jeong Bae Park ${ }^{b}$ \\ a Seoul National University Hospital and ${ }^{b}$ Cheil General Hospital, Seoul, South Korea
}

\section{Key Words}

Korean · Guidelines · Hypertension

\begin{abstract}
The Korean Society of Hypertension published new guidelines for the management of hypertension in 2013 which fully revised the first Korean hypertension treatment guideline published in 2004. Due to shortage of Korean data, the Committee decided to establish the guideline in the form of an 'adaptation' of the recently released guidelines. The prevalence of hypertension was $28.5 \%$ in the recent Korean National Health and Nutrition Examination Survey in 2011, and the awareness, treatment, and control rates are generally improving. However, the risks for cerebrovascular disease and coronary artery disease which are attributable to hypertension were the highest in Korea. The classification of hypertension is the same as in other guidelines. The remarkable difference is that prehypertension is further classified as stage 1 and 2 prehypertension because the cardiovascular risk is significantly different within the prehypertensive range. Although the decision-making was based on office blood pressure (BP) measured by the auscultation method using a stethoscope, the importance of home BP measurement and ambulatory BP monitoring is also stressed. The Korean guideline does not recommend a drug therapy in patients within the prehypertensive range, even in patients with prediabetes, diabetes mellitus, stroke, or coronary artery disease. In an elderly population over 65 years old, drug therapy can be initiated when the systolic BP (SBP) is $\geq 160 \mathrm{~mm} \mathrm{Hg}$. The target BP is generally an SBP of $<140 \mathrm{~mm} \mathrm{Hg}$ and a diastolic BP (DBP) of $<90 \mathrm{~mm} \mathrm{Hg}$ regardless of previous cardiovascular events. However, in patients with hypertension and diabetes, the lower DBP control $<85 \mathrm{~mm} \mathrm{Hg}$ is recommended. Also, in patients with hypertension with prominent albuminuria, a more strict SBP control $<130 \mathrm{~mm} \mathrm{Hg}$ can be recommended. In lifestyle modification, sodium reduction is the most important factor in Korea. Five classes of antihypertensive drugs, including angiotensin-converting enzyme inhibitors, $\beta$-blockers, calcium antagonists, and diuretics, are equally recommended as a first-line treatment, whereas a combination therapy chosen from renin-angiotensin system inhibitors, calcium antagonists, and diuretics is preferentially recommended.




\section{Introduction}

The Korean Society of Hypertension published new guidelines for the management of hypertension in 2013 which fully revised the first Korean hypertension treatment guideline published in 2004 [1]. A great amount of data from studies performed in Korea is needed to establish a treatment guideline perfectly tailored to our clinical practices; however, in reality, there is currently a serious shortage of available results from Korean studies. Practically speaking, it is difficult to construct an optimal guideline that physicians may apply exclusively to Korean patients. The Committee, therefore, decided to establish a guideline in the form of an 'adaptation' of the recently released guidelines including the guideline from the European Society of Hypertension/the European Society of Cardiology [2].

\section{The Prevalence and Clinical Significance of Hypertension in Korea}

In the Korean National Health and Nutrition Examination Survey (KNHANES), the agestandardized prevalence of hypertension was approximately $30 \%$ among adults aged $>30$ years of age. The temporal trend of the prevalence of hypertension was 29.9 and $28.6 \%$ in 1998 and 2001, respectively. This prevalence decreased slightly in 2007 and 2008 and then increased again in 2011 [3]. Among adults aged 65 years or older, the prevalence increased between 2007 and 2011 from 49.3 to $58.4 \%$ in men and from 61.8 to $68.9 \%$ in women. The prevalence of prehypertension in 2001 was $39.8 \%$ in men and $30.6 \%$ in women and decreased slightly to $28.4 \%$ in men and $18.8 \%$ in women in 2008 , similar to the trend in the prevalence of hypertension (table 1).

The Korean Medical Insurance Corporation (KMIC) study enrolled approximately 100,000 male civil officers and private school teachers to evaluate the risk of high blood pressure (BP). The risks for cerebrovascular disease and coronary artery disease which are attributable to hypertension in men were 35 and 21\%, respectively [4]. According to the KIMC study, the hazard ratio for cerebrovascular and coronary artery disease during a 6-year follow-up period was 2.6 for the hypertension group relative to the subjects with $\mathrm{BP}<130 / 85$ $\mathrm{mm} \mathrm{Hg} \mathrm{[5,6].} \mathrm{In} \mathrm{addition,} \mathrm{for} \mathrm{each} \mathrm{20-mm} \mathrm{Hg} \mathrm{increase} \mathrm{in} \mathrm{systolic} \mathrm{BP} \mathrm{(SBP),} \mathrm{the} \mathrm{relative} \mathrm{risks}$ of ischemic stroke, intracerebral hemorrhage, and subarachnoid hemorrhage were 1.79, 2.48, and 1.65, respectively, in men and 1.64, 3.15, and 2.29, respectively, in women [4]. Therefore, the risks of high BP for stroke and coronary artery disease in Korea have been well documented. Moreover, the risk of stroke is more clearly attributable to hypertension than that of coronary artery disease.

The awareness, treatment, and control rates are generally improving. According to the data from the KNHANES during the period from 2008 to 2011, the awareness rate was 58.5

Table 1. The trend in the prevalence of hypertension in the population aged $>30$ years (2011 National Health Statistics)

\begin{tabular}{lcccccccc}
\hline & $1980^{\mathrm{a}}$ & $1990^{\mathrm{a}}$ & $1998^{\mathrm{b}}$ & $2001^{\mathrm{b}}$ & $2005^{\mathrm{b}}$ & $2007^{\mathrm{b}}$ & $2008^{\mathrm{b}}$ & $2011^{\mathrm{b}}$ \\
\hline All & & & 29.9 & 28.6 & 28.0 & 24.6 & 26.3 & 28.5 \\
Male & 35.5 & 33.2 & 32.5 & 33.2 & 31.5 & 26.9 & 28.1 & 32.9 \\
Female & 26.9 & 25.4 & 26.9 & 25.4 & 23.9 & 21.8 & 23.9 & 23.7 \\
\hline
\end{tabular}

${ }^{a}$ The prevalence in 1980 and 1990 was based on the nationwide study for the prevalence of hypertension. ${ }^{\mathrm{b}}$ Age-adjusted for the estimated population in 2005 . 
and $76.1 \%$ among men and women aged $>30$ years, respectively, which was an improvement relative to the previous data (table 2). The treatment rate in 2001 was 22.2 and $37.5 \%$ in men and women, respectively, according to the in-depth report of the KNHANES 2005, which improved to 51.7 and $71.3 \%$ in men and women, respectively, in the 2008-2011 period (table 2). The control rate in 2001 was quite low at 9.9 and $18.0 \%$ in men and women, respectively. However, as of the 2008-2011 period, it had increased to 36.9 and $49.4 \%$ in men and women, respectively (table 2). Although there was no clear change in the prevalence of hypertension, the mean BP has steadily decreased, especially among patients with hypertension.

\section{Office BP-Centered Approach and Subdivision of the Prehypertension Category}

Hypertension is defined as an SBP or a diastolic blood pressure (DBP) $\geq 140$ or $\geq 90 \mathrm{~mm}$ $\mathrm{Hg}$, respectively. Normal BP is defined only as both an SBP $<120 \mathrm{~mm} \mathrm{Hg}$ and a DBP $<80 \mathrm{~mm}$ $\mathrm{Hg}$. When SBP is $\geq 120$ but $<140 \mathrm{~mm} \mathrm{Hg}$ and/or DBP is $\geq 80$ but $<90 \mathrm{~mm} \mathrm{Hg}$, the patient is considered to have prehypertension. The remarkable difference is that prehypertension is further classified as stage 1 and 2 prehypertension. In stage 1 prehypertension, SBP is $\geq 120$ but $<130 \mathrm{~mm} \mathrm{Hg}$ and/or DBP is $\geq 80$ but $<85 \mathrm{~mm} \mathrm{Hg}$. In stage 2 prehypertension, SBP is $\geq 130$ but $<140 \mathrm{~mm} \mathrm{Hg}$ and/or DBP is $\geq 85$ but $<90 \mathrm{~mm} \mathrm{Hg}$. The reason for this subdivision is that the cardiovascular risk is significantly different within the prehypertensive range. For example, in the KMIC study, the risk of coronary artery disease was 2.51-fold higher in the stage 2 prehypertension group than in the stage 1 prehypertension group [6, 7]. In addition, the probability of progressing to hypertension and the risk for a cardiovascular event were both reported to be higher in the prehypertension group than in the normal BP group [8-10]. In another paper from the KMIC study, a BP >135/85 mm Hg was associated with the occurrence of hemorrhagic stroke in male subjects. Hypertension is further classified as stage 1 and 2 hypertension as shown in table 3.

Table 2. Trends in the management of hypertension (standardized for Census 2005, National Health Statistic)

\begin{tabular}{lrccc}
\hline & 1998 & 2001 & 2005 & $2008-2011$ \\
\hline Awareness & 27.0 & 36.0 & 59.8 & 66.9 \\
Treatment rate & 19.1 & 29.3 & 47.1 & 61.1 \\
Control rate for all hypertension patients & 7.4 & 14.9 & 32.2 & 42.9 \\
Control rate for treated hypertension patients & 22.9 & 37.0 & 54.9 & 69.3 \\
\hline
\end{tabular}

Values are presented as percentages. The criterion for patients with treatment of hypertension was taking antihypertensive drugs on $>20$ days per month.

Table 3. The classification of BP and hypertension

\begin{tabular}{llclc}
\hline & Category & SBP, mm Hg & & DBP, mm Hg \\
\hline Normal BP & & $<120$ & and & $<80$ \\
\hline Prehypertension & stage 1 & $120-129$ & or & $80-84$ \\
& stage 2 & $130-139$ & or & $85-89$ \\
\hline Hypertension & stage 1 & $140-159$ & or & $90-99$ \\
& stage 2 & 160 & or & 100 \\
\hline Isolated systolic hypertension & & 140 & and & $<90$ \\
\hline
\end{tabular}




\begin{tabular}{|c|c|c|}
\hline \multicolumn{3}{|l|}{ Pulse 2015;3:21-28 } \\
\hline \multicolumn{2}{|l|}{ DOI: $10.1159 / 000381994$} & $\begin{array}{l}\text { (C) } 2015 \text { S. Karger AG, Basel } \\
\text { www.karger.com/pls }\end{array}$ \\
\hline \multicolumn{3}{|c|}{$\begin{array}{l}\text { Lee and Park: The Korean Society of Hypertension Guidelines for the Management o } \\
\text { Hypertension in 2013: Its Essentials and Key Points }\end{array}$} \\
\hline & $\mathrm{SBP}, \mathrm{mm} \mathrm{Hg}$ & DBP, mm Hg \\
\hline Clinic or office BP & $\geq 140$ & $\geq 90$ \\
\hline \multicolumn{3}{|l|}{ Ambulatory BP } \\
\hline 24-hour & $\geq 130$ & $\geq 80$ \\
\hline Day & $\geq 135$ & $\geq 85$ \\
\hline Night & $\geq 120$ & $\geq 70$ \\
\hline Home BP & $\geq 135$ & $\geq 85$ \\
\hline
\end{tabular}

Table 4. Criteria for the definition of hypertension with different methods of measurement

The decision-making in the Korean guideline of hypertension was based on the office BP measured by the auscultation method using a stethoscope. However, the guideline also stressed the importance of home BP measurement and ambulatory BP monitoring to diagnose white-coat hypertension, masked hypertension, and resistant hypertension, to titrate the dosage of antihypertensive drugs, and to improve the patient compliance [11]. Hypertension can be diagnosed when home BP or mean daytime BP is $\geq 135 / 85 \mathrm{~mm} \mathrm{Hg}$ (table 4). When making a diagnosis of hypertension based on home BP measurement, it is recommended to measure at least on 5 consecutive days in a week and to perform 1-3 measurements in each session in the morning and evening. In the morning, BP is measured after voiding, within $1 \mathrm{~h}$ of awakening, and before taking antihypertensive drugs. In the evening, it is measured before sleep. When calculating the mean BP, the readings on the first day are usually omitted.

In 'out-of-office' BP measurement, white-coat hypertension and masked hypertension need to be considered. The KorABP registry in secondary or tertiary referral centers supported by the Korean Society of Hypertension reported that $14.9 \%$ of patients were found to have white-coat hypertension, and masked hypertension was observed in $17.6 \%$ of 1,916 subjects who underwent ambulatory BP monitoring for the diagnosis of hypertension [12].

\section{Comprehensive Risk Stratification for Hypertension Care}

The risk stratification of hypertension was based on the KMIC data, which were drawn from patients with the following characteristics: (1) registered in the early 1990s; (2) relatively young age range of 35-59 years, and (3) relatively high socioeconomic status [13]. The lowest risk for a cardiovascular event in the KMIC data was $2-3$ or $2.5 \%$ among the patients in their 40s. According to the guidelines presenting risk group by cardiovascular event rates $[14,15]$, the average-risk group included those patients with a risk approximately 2 -fold higher than that of the lowest-risk group, corresponding to a 10-year cardiovascular event rate of $5 \%$. The moderate added-risk group was defined as the patients with a risk $\geq 2$-fold higher than that of the average-risk group, i.e. a 10 -year cardiovascular event rate of $\geq 10 \%$. The high added-risk group was defined as the group with a risk $\geq 2$-fold higher than that of the moderate added-risk group, i.e. a 10 -year cardiovascular event rate of $\geq 20 \%$. Therefore, the 10-year cardiovascular event rates for the lowest-, average-, low added-, moderate added-, and high added- (including the highest added-) risk groups were 2.5, 5, 5-10, 10-15, and $\geq 15 \%$, respectively, after consideration of the potential underestimation; these levels correspond to the cardiovascular event rates of 2.5, 5, 5-15, 15-20, and 20\% in the European guidelines [14-16]. Patients with stage 1 hypertension who are in their 40 s and have no other cardiovascular risk factors have a risk of 4.3-5.3\%; some of them may be at above-average risk, whereas the women in this group are at below-average risk, i.e. 4.0-4.9\%. The cardiovascular risk was stratified using the BP level, number of risk factors, evidence of subclinical organ damage, and clinical cardiovascular diseases, as shown in table 5. 
Table 5. Stratification of global cardiovascular events for hypertensive patients

\begin{tabular}{|c|c|c|c|}
\hline \multirow[t]{2}{*}{ Risk profile } & \multicolumn{3}{|l|}{$\mathrm{BP}$} \\
\hline & $\begin{array}{l}\text { stage } 2 \text { prehypertension } \\
(130-139 / 85-89 \mathrm{~mm} \mathrm{Hg})\end{array}$ & $\begin{array}{l}\text { stage } 1 \text { hypertension } \\
(140-159 / 90-99 \mathrm{~mm} \mathrm{Hg})\end{array}$ & $\begin{array}{l}\text { stage } 2 \text { hypertension } \\
(\geq 160 / 100 \mathrm{~mm} \mathrm{Hg})\end{array}$ \\
\hline Risk factors: 0 & Lowest-risk group & Low added-risk group & $\begin{array}{l}\text { Moderate to high } \\
\text { added-risk group }\end{array}$ \\
\hline Risk factors other than DM: $1-2$ & $\begin{array}{l}\text { Low to moderate added-risk } \\
\text { group }\end{array}$ & Moderate added-risk group & High added-risk group \\
\hline $\begin{array}{l}\text { Risk factors: } \geq 3 \text { or subclinical } \\
\text { organ damage }\end{array}$ & $\begin{array}{l}\text { Moderate to high added-risk } \\
\text { group }\end{array}$ & High added-risk group & High added-risk group \\
\hline $\begin{array}{l}\text { DM, cardiovascular diseases, } \\
\text { chronic kidney disease }\end{array}$ & High added-risk group & High added-risk group & High added-risk group \\
\hline
\end{tabular}

Risk factors: age (men $\geq 45$ years old, women $\geq 55$ years old), smoking, obesity (or abdominal obesity), dyslipidemia, impaired fasting glucose or impaired glucose tolerance, family history of premature cardiovascular disease, and DM. The 10-year cardiovascular event rates for the lowest-, average-, low added-, moderate added-, and high added- (including the highest added-) risk groups were $2.5,5,5-10,10-15$, and $\geq 15 \%$, respectively, according to Korean Medical Insurance Company Study data. DM = Diabetes mellitus.

Table 6. Summary of the target BPs in hypertension treatment

\begin{tabular}{lll}
\hline & SBP, mm Hg & DBP, mm Hg \\
\hline Uncomplicated hypertension & 140 & 90 \\
Elderly & $140-150$ & 90 \\
Diabetes mellitus & 140 & 85 \\
Stroke & 140 & 90 \\
Coronary artery disease & 140 & 90 \\
Chronic kidney disease & & \\
$\quad$ Without albuminuria & 140 & 90 \\
\multicolumn{1}{c}{ With albuminuria } & 130 & 80 \\
\hline
\end{tabular}

a Microalbuminuria or macroalbuminuria.

\section{Principles of Treatment}

The Korean guideline does not recommend a drug therapy in patients within the prehypertensive range, even in patients with prediabetes [17, 18], diabetes mellitus [19], stroke [20], or coronary artery disease [21]. In an elderly population over 65 years old, drug therapy can be initiated when the SBP is $\geq 160 \mathrm{~mm} \mathrm{Hg}$.

The target BP is generally an SBP of $<140 \mathrm{~mm} \mathrm{Hg}$ and a DBP of $<90 \mathrm{~mm} \mathrm{Hg}$ (table 6) [2224]. In the elderly, the target SBP is approximately $140-150 \mathrm{~mm} \mathrm{Hg}$ with a DBP that is not excessively low, i.e. less than approximately $60 \mathrm{~mm} \mathrm{Hg}[25,26]$. In patients with hypertension and diabetes, the recommended target $\mathrm{BP}$ is an SBP $<140 \mathrm{~mm} \mathrm{Hg}$ [27] and a DBP $<85 \mathrm{~mm} \mathrm{Hg}$ [28]. In patients with previous cardiovascular disease including stroke, a reduction of SBP to $<130 \mathrm{~mm} \mathrm{Hg}$ shows no consistent prevention [29-33]. Therefore, a target SBP of $<140 \mathrm{~mm}$ $\mathrm{Hg}$ is recommended. In patients with chronic kidney disease, further control of SBP to $<140$ $\mathrm{mm} \mathrm{Hg}$ has shown no additional benefit [34-36]. A meta-analysis has not proven that a target $\mathrm{BP}$ of $<140 \mathrm{~mm} \mathrm{Hg}$ is any more effective at preventing cardiac and renal events, either [27, $37,38]$. Therefore, a target SBP of $<140 \mathrm{~mm} \mathrm{Hg}$ is recommended regardless of the presence of diabetes. However, a target SBP $<130 \mathrm{~mm} \mathrm{Hg}$ can be recommended in patients with hypertension with prominent albuminuria [2]. 
Fig. 1. Recommended combination therapy. Thick lines indicate preferred combination, and thin lines indicate feasible combination. $\mathrm{ARB}=$ Angiotensin receptor blocker; $\mathrm{ACE}$ = angiotensin-converting enzyme.

Lee and Park: The Korean Society of Hypertension Guidelines for the Management of Hypertension in 2013: Its Essentials and Key Points

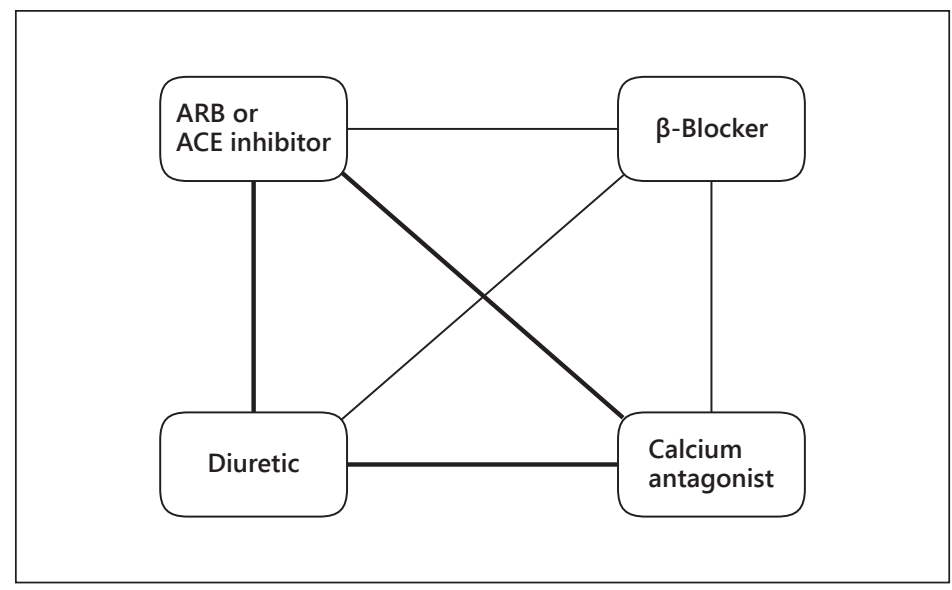

In lifestyle modification, sodium reduction is the most important factor in non-drug treatment, because the estimated daily salt intake according to the 2010 KNHANES is $4.9 \mathrm{~g}$ of sodium, which is a higher amount than in western or Japanese populations [39].

\section{Key Points in Pharmacologic Treatment}

Five classes of antihypertensive drugs, including angiotensin-converting enzyme inhibitors, $\beta$-blockers, calcium antagonists, and diuretics, were equally recommended as a firstline treatment. There is no uniform consensus on the role of $\beta$-blockers in elderly patients with hypertension, so prescription of $\beta$-blockers in the elderly should be limited to special circumstances. $\beta$-Blockers should also be used with care in patients at high risk for diabetes, because in combination with diuretics, they can increase the risk of new onset of diabetes [2]. In patients with $\mathrm{BP}>160 / 100 \mathrm{~mm} \mathrm{Hg}$ or more than $20 / 10 \mathrm{~mm} \mathrm{Hg}$ above the target BP, two drugs can be prescribed in combination to maximize the antihypertensive effect and achieve rapid $\mathrm{BP}$ control [2].

If $\mathrm{BP}$ is not controlled with a single drug, two drugs should be combined for BP control. Combination therapy is more effective than single-drug therapy at a higher dose [40]. Combination therapy chosen from the renin-angiotensin system inhibitors, calcium antagonists, and diuretics is recommended first because it has shown relatively good results [23, 41, 42], but $\beta$-blockers can also be combined with drugs of other classes (fig. 1). However, the combination of $\beta$-blockers and diuretics can increase the incidence of diabetes and metabolic disorders and thus requires periodic monitoring.

\section{Summary and Conclusion}

With limited outcome data in Korea, the Guideline Committee of the Korean Society of Hypertension adopted other hypertension guidelines and modified them to our situation through a transparent guideline development process. Therefore, we think this guideline will be particularly useful for Koreans and guide hypertension diagnosis and management for health-care professionals in Korea. 


\section{References}

1 Shin J, Park JB, Kim K, Kim JH, Yang DH, Pyun WB, Kim YG, Kim GH, et al: 2013 Korean Society of Hypertension guidelines for the management of hypertension. Part I - epidemiology and diagnosis of hypertension. Clin Hypertens 2015;21:1.

-2 Mancia G, Fagard R, Narkiewicz K, Redon J, Zanchetti A, Bohm M, Christiaens T, Cifkova R, De Backer G, Dominiczak A, Galderisi M, Grobbee DE, Jaarsma T, Kirchhof P, Kjeldsen SE, Laurent S, Manolis AJ, Nilsson PM, Ruilope LM, Schmieder RE, Sirnes PA, Sleight P, Viigimaa M, Waeber B, Zannad F; Task Force Members: 2013 ESH/ESC guidelines for the management of arterial hypertension: the task force for the management of arterial hypertension of the European Society of Hypertension (ESH) and of the European Society of Cardiology (ESC). J Hypertens 2013;31:1281-1357.

3 Kim HC, Oh SM: Noncommunicable diseases: current status of major modifiable risk factors in Korea. J Prev Med Public Health 2013;46:165-172.

$>4$ Kim HC, Nam CM, Jee SH, Suh I: Comparison of blood pressure-associated risk of intracerebral hemorrhage and subarachnoid hemorrhage: Korea Medical Insurance Corporation study. Hypertension 2005;46:393-397.

5 Jee SH, Appel LJ, Suh I, Whelton PK, Kim IS: Prevalence of cardiovascular risk factors in South Korean adults: results from the Korea Medical Insurance Corporation (KMIC) Study. Ann Epidemiol 1998;8:14-21.

6 Park JK, Kim CB, Kim KS, Kang MG, Jee SH: Meta-analysis of hypertension as a risk factor of cerebrovascular disorders in Koreans. J Korean Med Sci 2001;16:2-8.

7 Kim KS, Ryu SY, Park JK, Kim CB, Chun BY, Lee TY, Lee KS, Lee DH, Koh KW, Jee SH, Suh I: A nested case control study on risk factors for coronary heart disease in Korean. Korean J Prev Med 2001;34:149-156.

-8 Arima H, Murakami Y, Lam TH, Kim HC, Ueshima H, Woo J, Suh I, Fang X, Woodward M; Asia Pacific Cohort Studies Collaboration: Effects of prehypertension and hypertension subtype on cardiovascular disease in the Asia-Pacific region. Hypertension 2012;59:1118-1123.

-9 Kim SJ, Lee J, Nam CM, Jee SH, Park IS, Lee KJ, Lee SY: Progression rate from new-onset pre-hypertension to hypertension in Korean adults. Circ J 2011;75:135-140.

10 Kim SJ, Lee J, Jee SH, Nam CM, Chun K, Park IS, Lee SY: Cardiovascular risk factors for incident hypertension in the prehypertensive population. Epidemiol Health 2010;32:e2010003.

11 Cappuccio FP, Kerry SM, Forbes L, Donald A: Blood pressure control by home monitoring: meta-analysis of randomised trials. BMJ 2004;329:145.

-12 Shin J, Park SH, Kim JH, Ihm SH, Kim G, Kim WS, Kim YM, Pyun WB, Choi SI, Kim SK: Discordance between ambulatory versus clinic blood pressure according to the global cardiovascular risk groups. Kor J Intern Med 2014, in press.

13 Committee for Establishing Treatment Instruction for Dyslipidemia of the Korean Society of Lipidology and Atherosclerosis: Guidelines for Management of Dyslipidemia, ed 2. Seoul, Korean Society of Lipidology and Atherosclerosis, 2009.

$\checkmark 14$ European Society of Hypertension-European Society of Cardiology Guidelines Committee: 2003 European Society of Hypertension-European Society of Cardiology guidelines for the management of arterial hypertension. J Hypertens 2003;21:1011-1053.

-15 1999 World Health Organization-International Society of Hypertension guidelines for the management of hypertension. Guidelines Subcommittee. J Hypertens 1999;17:151-183.

16 Mancia G, De Backer G, Dominiczak A, et al; the task force for the management of arterial hypertension of the European Society of Hypertension; the task force for the management of arterial hypertension of the European Society of Cardiology: 2007 guidelines for the management of arterial hypertension: the task force for the management of arterial hypertension of the European Society of Hypertension (ESH) and of the European Society of Cardiology (ESC). Eur Heart J 2007;28:1462-1536.

17 Dagenais GR, Gerstein HC, Holman R, Budaj A, Escalante A, Hedner T, Keltai M, Lonn E, McFarlane S, McQueen M, Teo K, Sheridan P, Bosch J, Pogue J, Yusuf S: Effects of ramipril and rosiglitazone on cardiovascular and renal outcomes in people with impaired glucose tolerance or impaired fasting glucose: results of the Diabetes Reduction Assessment with Ramipril and Rosiglitazone Medication (DREAM) trial. Diabetes Care 2008;31: 1007-1014.

18 McMurray JJ, Holman RR, Haffner SM, et al: Effect of valsartan on the incidence of diabetes and cardiovascular events. N Engl J Med 2010;362:1477-1490.

-19 Schrier RW, Estacio RO, Esler A, Mehler P: Effects of aggressive blood pressure control in normotensive type 2 diabetic patients on albuminuria, retinopathy and strokes. Kidney Int 2002;61:1086-1097.

20 Arima H, Chalmers J, Woodward M, Anderson C, Rodgers A, Davis S, Macmahon S, Neal B; PROGRESS Collaborative Group: Lower target blood pressures are safe and effective for the prevention of recurrent stroke: the PROGRESS trial. J Hypertens 2006;24:1201-1208.

-21 Zanchetti A, Amery A, Berglund G, Cruickshank JM, Hansson L, Lever AF, Sleight P: How much should blood pressure be lowered? The problem of the J-shaped curve. J Hypertens Suppl 1989; 7:S338-S348.

22 Zanchetti A, Grassi G, Mancia G: When should antihypertensive drug treatment be initiated and to what levels should systolic blood pressure be lowered? A critical reappraisal. J Hypertens 2009;27:923-934.

23 Liu L, Zhang Y, Liu G, Li W, Zhang X, Zanchetti A; FEVER Study Group: The Felodipine Event Reduction (FEVER) Study: a randomized long-term placebo-controlled trial in Chinese hypertensive patients. J Hypertens 2005; 23:2157-2172. 
Lee and Park: The Korean Society of Hypertension Guidelines for the Management of Hypertension in 2013: Its Essentials and Key Points

24 Zhang Y, Zhang X, Liu L, Zanchetti A; FEVER Study Group: Is a systolic blood pressure target < 140 mm Hg indicated in all hypertensives? Subgroup analyses of findings from the randomized FEVER trial. Eur Heart J 2011; 32:1500-1508.

25 JATOS Study Group: Principal results of the Japanese trial to assess optimal systolic blood pressure in elderly hypertensive patients (JATOS). Hypertens Res 2008;31:2115-2127.

-26 Ogihara T, Saruta T, Rakugi H, Matsuoka H, Shimamoto K, Shimada K, Imai Y, Kikuchi K, Ito S, Eto T, Kimura G, Imaizumi T, Takishita S, Ueshima H; Valsartan in Elderly Isolated Systolic Hypertension Study Group: Target blood pressure for treatment of isolated systolic hypertension in the elderly: valsartan in elderly isolated systolic hypertension study. Hypertension 2010;56:196-202.

-27 ACCORD Study Group; Cushman WC, Evans GW, Byington RP, Goff DC Jr, Grimm RH Jr, Cutler JA, SimonsMorton DG, Basile JN, Corson MA, Probstfield JL, Katz L, Peterson KA, Friedewald WT, Buse JB, Bigger JT, Gerstein HC, Ismail-Beigi F: Effects of intensive blood-pressure control in type 2 diabetes mellitus. N Engl J Med 2010;362:1575-1585.

-28 Hansson L, Zanchetti A, Carruthers SG, Dahlof B, Elmfeldt D, Julius S, Menard J, Rahn KH, Wedel H, Westerling S: Effects of intensive blood-pressure lowering and low-dose aspirin in patients with hypertension: principal results of the Hypertension Optimal Treatment (HOT) randomised trial. HOT Study Group. Lancet 1998;351: 1755-1762.

29 Fox KM; European Trial on Reduction of Cardiac Events with Perindopril in Stable Coronary Artery Disease Investigators: Efficacy of perindopril in reduction of cardiovascular events among patients with stable coronary artery disease: randomised, double-blind, placebo-controlled, multicentre trial (the EUROPA study). Lancet 2003;362:782-788.

-30 Poole-Wilson PA, Lubsen J, Kirwan BA, van Dalen FJ, Wagener G, Danchin N, Just H, Fox KA, Pocock SJ, Clayton TC, Motro M, Parker JD, Bourassa MG, Dart AM, Hildebrandt P, Hjalmarson A, Kragten JA, Molhoek GP, Otterstad JE, Seabra-Gomes R, Soler-Soler J, Weber S; Coronary Disease Trial Investigating Outcome with Nifedipine Gastrointestinal Therapeutic System Investigators: Effect of long-acting nifedipine on mortality and cardiovascular morbidity in patients with stable angina requiring treatment (ACTION trial): randomised controlled trial. Lancet 2004;364:849-857.

-31 Braunwald E, Domanski MJ, Fowler SE, Geller NL, Gersh BJ, Hsia J, Pfeffer MA, Rice MM, Rosenberg YD, Rouleau JL; PEACE Trial Investigators: Angiotensin-converting-enzyme inhibition in stable coronary artery disease. N Engl J Med 2004;351:2058-2068.

-32 Ovbiagele B, Diener HC, Yusuf S, Martin RH, Cotton D, Vinisko R, Donnan GA, Bath PM; PROFESS Investigators: Level of systolic blood pressure within the normal range and risk of recurrent stroke. JAMA 2011;306:2137-2144.

33 Yusuf S, Diener HC, Sacco RL, Cotton D, Ounpuu S, Lawton WA, Palesch Y, Martin RH, Albers GW, Bath P, Bornstein N, Chan BP, Chen ST, Cunha L, Dahlof B, De Keyser J, Donnan GA, Estol C, Gorelick P, Gu V, Hermansson K, Hilbrich L, Kaste M, Lu C, Machnig T, Pais P, Roberts R, Skvortsova V, Teal P, Toni D, VanderMaelen C, Voigt T, Weber M, Yoon BW; PROFESS Study Group: Telmisartan to prevent recurrent stroke and cardiovascular events. N Engl J Med 2008;359:1225-1237.

-34 Klahr S, Levey AS, Beck GJ, Caggiula AW, Hunsicker L, Kusek JW, Striker G: The effects of dietary protein restriction and blood-pressure control on the progression of chronic renal disease. Modification of Diet in Renal Disease Study Group. N Engl J Med 1994;330:877-884.

-35 Wright JT Jr, Bakris G, Greene T, Agodoa LY, Appel LJ, Charleston J, Cheek D, Douglas-Baltimore JG, Gassman J, Glassock R, Hebert L, Jamerson K, Lewis J, Phillips RA, Toto RD, Middleton JP, Rostand SG; African American Study of Kidney Disease and Hypertension Study Group: Effect of blood pressure lowering and antihypertensive drug class on progression of hypertensive kidney disease: results from the AASK trial. JAMA 2002;288:2421-2431.

-36 Ruggenenti P, Perna A, Loriga G, Ganeva M, Ene-Iordache B, Turturro M, Lesti M, Perticucci E, Chakarski IN, Leonardis D, Garini G, Sessa A, Basile C, Alpa M, Scanziani R, Sorba G, Zoccali C, Remuzzi G; REIN-2 Study Group: Blood-pressure control for renoprotection in patients with non-diabetic chronic renal disease (REIN-2): multicentre, randomised controlled trial. Lancet 2005;365:939-946.

37 Arguedas JA, Perez MI, Wright JM: Treatment blood pressure targets for hypertension. Cochrane Database Syst Rev 2009;CD004349.

38 Upadhyay A, Earley A, Haynes SM, Uhlig K: Systematic review: blood pressure target in chronic kidney disease and proteinuria as an effect modifier. Ann Intern Med 2011;154:541-548.

39 Korea Centers for Disease Control and Prevention: 2010 Korean National Health Statistics. 2010 Korean National Health and Nutrition Examination Survey (KNHANES). Cheongju, Korea Centers for Disease Control and Prevention, 2010.

40 Wald DS, Law M, Morris JK, Bestwick JP, Wald NJ: Combination therapy versus monotherapy in reducing blood pressure: meta-analysis on 11,000 participants from 42 trials. Am J Med 2009;122:290-300.

-41 Patel A, MacMahon S, Chalmers J, Neal B, Woodward M, Billot L, Harrap S, Poulter N, Marre M, Cooper M, Glasziou P, Grobbee DE, Hamet P, Heller S, Liu LS, Mancia G, Mogensen CE, Pan CY, Rodgers A, Williams B; ADVANCE Collaborative Group: Effects of a fixed combination of perindopril and indapamide on macrovascular and microvascular outcomes in patients with type 2 diabetes mellitus (the ADVANCE trial): a randomised controlled trial. Lancet 2007;370:829-840.

-42 Jamerson K, Weber MA, Bakris GL, Dahlof B, Pitt B, Shi V, Hester A, Gupte J, Gatlin M, Velazquez EJ; ACCOMPLISH Trial Investigators: Benazepril plus amlodipine or hydrochlorothiazide for hypertension in high-risk patients. N Engl J Med 2008;359:2417-2428. 